\title{
1. World trade law and changing fundamentals in the global architecture
}

In recent decades, international law, and in particular international economic law, has been greatly impacted by globalisation and the emergence of global governance. Unlike other processes of norm-making in international economic law, the influence of globalisation on international trade law is sometimes very subtle but also very far-reaching and usually goes unnoticed. The World Trade Organization (WTO) is an engine for trade liberalisation and the promotion of economic growth, and is therefore considered to be firmly rooted in the idea of globalisation and interconnectivity. While the notion of globalisation is not new, the increasing integration of commodity, capital and labour markets has undoubtedly altered the landscape of the global trading system over the past few decades. ${ }^{1}$ Globalisation is a multidimensional construct whose meaning largely depends on the context in which it is discussed. While it is viewed in this volume in the light of greater economic integration of the different factors of production, academic scholarship has also approached it from other perspectives. Joseph Stiglitz, winner of the 2001 Nobel Prize in economics for his outstanding work on the 'theory of market with asymmetric information', described the concept of globalisation in his seminal work entitled Globalization and its Discontents (2002) as 'the closer integration of the countries and peoples of the world which has been brought about by the enormous reduction of costs of transportation and communication, and the breaking down of artificial barriers to the

\footnotetext{
1 Some of these analyses are very much reflected in Ngangjoh-Hodu, Theories and Practices of Compliance with WTO Law (Kluwer, 2012) (hereinafter 'NgangjohHodu (2012)'). There is no universally agreed definition of globalisation. However, international integration in labour, commodity and capital markets is usually used by economists to mean globalisation. On this, see Michael D. Bordo, Antu Panini Murshid, 'Globalization and Changing Patterns in the International Transmission of Shocks in Financial Markets', Journal of International Money and Finance (JIMF), Vol. 25 (2006), pp. 655-74.
} 
flow of goods, services, capital, knowledge, and (to a lesser extent) people across borders' ${ }^{2}$

Given the continuous connectivity of global activities to the fabric of our different municipal societies, we cannot overestimate the rate at which international economic law has become enmeshed in our national legal systems. While international economic lawyers need to familiarise themselves with certain domestic concepts to be able to conduct their day-to-day activities, domestic lawyers would hardly be capable of engaging in litigation on a sound basis without knowledge of key aspects of international law. In other words, the international law of trade is becoming more important than ever before in the municipal systems of the 160 WTO members. Despite the fact that the discourse on globalisation and its effects on our day-to-day lives depends on the perspective from which one conceptualises this relationship, the nexus between the WTO and globalisation is to a great extent no longer in dispute. For international traders in goods and services, the notion of economic globalisation implies better market access for their products to more competitive foreign markets. From the standpoint of everyday consumers of goods and services, economic globalisation implies the easy availability of competitive foreign products as well as cheaper domestic products as a consequence of the competition that accompanies trade liberalisation.

Although the effects of globalisation are sometimes exaggerated, it is nevertheless clear that it has facilitated the distribution of goods and services on the international markets. Yet, as with all engagements, it is in the interest of the community of nations who are parties to the global trade project to cultivate an attitude of compliance with these international law obligations. As international trade norms evolve, so too does the way in which private actors and governments view the remedies that accompany those norms. The notion of remedies as a traditional fall-back option for non-compliance with international obligations is germane to our understanding of how international trade rules have been influenced by globalisation. This is so despite the increasing difficulties involved in achieving 'hard law' in international trade norm-making as opposed to the soft law which has typified most of the debates and trade negotiations in recent years.

Some 12 years ago, Supachai Panitchpakdi, the then WTO Director General, selected a group of eight persons, mostly from the private sector,

2 See Joseph Stiglitz, Globalization and its Discontents (Pengiun Books, 2002), p.9. See also an earlier work on globalisation by Thomas Friedmas, The Lexus and the Olive Tree: Understanding Globalisation (First Anchor Books, 2nd ed., 2000). 
to examine some key institutional challenges facing the world trading system and make proposals on how to improve it. Many, if not all, of the challenges facing the WTO in 2005 when the consultative team carried out its tasks are as relevant today as they were then. Apart from the Bali 2013 Package, ${ }^{3}$ no conclusion has been reached on any of the issues under the Doha trade talks agenda. Although two such requests for outside help had been made under the troubled GATT (1948-1994), this was the first time since the establishment of the WTO in 1995 that the institution had established an external board to examine and provide input on how to shape the WTO to meet the challenges of the twenty-first century. ${ }^{4}$ The first group, appointed by the GATT contracting parties in 1947, consisted of three experts (and later four), and was chaired by Professor Gottfried Haberler, an economist from Harvard University. Their report, commonly referred to as the 'Haberler Report', appeared in 1958. Their mandate included, among other things, assessing the reasons why lessdeveloped countries' trade had failed to develop as rapidly as that of the industrialised countries. About 25 years later, Director General Arthur Dunkel requested another group of independent experts to study and report on the problems facing the international trading system. This group comprised seven members and was chaired by Fritz Leutwiler. The 2003 consultative board was made up of renowned personalities from different parts of the world and was largely representative of the WTO membership. ${ }^{5}$ On 17 January 2005 it issued its long-awaited report,

3 Consistent with the WTO Ministerial Decision of December 2013 in Bali, the members of the WTO on 27 November 2014 adopted a Protocol of Amendment to incorporate the Bali Trade Facilitation Agreement into Annex 1A of the Marrakesh Agreement Establishing the WTO. In this regard the Trade Facilitation Agreement will enter into force once a two-thirds majority of WTO members have ratified it domestically. The agreement is available at https://www. wto.org/english/tratop_e/tradfa_e/tradfa_e.htm (last visited 11 May 2015).

4 The Leutwiler Report offered 15 recommendations, which were lauded for giving perspectives to negotiators during the 1986 launching of the Uruguay Round.

5 The board members were as follows: Peter Sutherland (former Director General of the GATT and the WTO between 1993 and 1995), who chaired the group, Jagdish Bagwati (Professor, Columbia University), Kwesi Botchwey (Executive Chairman, African Development Policy Ownership Initiative), Niall FitzGerald (Chairman, Reuters), Koichi Hamada (Professor, Yale University), John H. Jackson (Professor, Georgetown University), Celso Lafer (Professor, University of São Paulo), Thierry de Montbrial (President and Founder, French Institute of International Relations). However, there has been some criticism as to the board members chosen. In this regard, see Armin von Bogdandy and Markus Wagner, 'The "Sutherland Report" on WTO Reform - A Critical Appraisal', 
entitled The Future of the WTO: Addressing Institutional Challenges in the New Millennium. ${ }^{6}$

Since the launch of the Sunderland Report published at the tenth anniversary of the WTO, it has been difficult to identify any major normative change in respect of some of the key difficulties that led to the establishment of the consultative board, let alone the implementation of the recommendations made in the Sutherland Report. Despite persistent efforts by many WTO members to address key institutional and normative challenges facing the world trading system, 'constructive ambiguity' continues to be the modus operandi in WTO negotiations. Notwithstanding the December 2013 Bali Package on trade facilitation and food security, the so-called Doha Development Round remains far from concluded almost 15 years from being launched. ${ }^{7}$ As a consequence of the consensus and single undertaking principles used in decision-making at the WTO, everyone must be on board for a decision to be considered as approved in the context of the Doha Development trade talks. In other words, 'nothing is agreed until everything is agreed'. ${ }^{8}$ Therefore, the promised reform to clarify and amend some of the provisions of the WTO Dispute Settlement Understanding (DSU) as part of the Doha Development Round of trade negotiations has failed to move forward as originally agreed by members. ${ }^{9}$ The circumstances leading to the establishment

World Trade Review, Vol. 4, No. 3, pp. 439-47 (2005) (hereinafter, 'von Bogdandy and Markus Wagner').

6 Chapter 6 of the report contains an 11-page document dealing with dispute settlement reform. The report is available at: http://www.wto.org/english/ thewto_e/10anniv_e/future_wto_e.pdf (last visited 5 September 2014).

7 The euphoria that followed the signing of the Bali Package on trade facilitation and food security seems to have faded away as WTO members could not agree on the required protocol by the 31 July 2014 deadline to adopt it in WTO legal text. See the December 2013 WTO Ninth Ministerial Conference Decision in WTO Document, WT/MIN(13)/36 (December 2013).

8 The Punta Del Este Declaration, which launched the Uruguay Round of trade talks, directed the contracting parties to treat the conduct of the negotiations, and their conclusion, as a single process - in other words, to consider any agreement arrived at as a single undertaking as opposed to the obligations under the GATT. Currently, the term 'single undertaking' is understood as a requirement that WTO members must join all the agreements administered by it, except for the plurilateral agreements on Civil Aircraft and Government Procurement. The Doha Ministerial Declaration also directs members to factor in the single undertaking principle in the negotiations. See para. 47 of the Doha Ministerial Declaration, WT/MIN(01)/DEC/1, adopted on 14 November 2001.

9 Doha WTO Ministerial 2001: Ministerial Declaration, WT/MIN(01)/ DEC/1, 20 November 2001, para. 30. See also para. 34 of the Hong Kong Ministerial Declaration (adopted 18 December 2005). 
of the consultative board were neither unique nor new. When the new dispute settlement system was established to replace the troubled GATT dispute settlement structure in 1994, some fundamental questions still remained to be answered as to how the new two-tier system was going to operate in practice. In view of the fact that it was likely that certain changes might be introduced on the strength of the experience acquired, ministers undertook at the conclusion of the Uruguay Round in 1995 to 'complete a full review of dispute settlement rules and procedures within four years after the entry into force of the Agreement Establishing the WTO, and to take a decision on the occasion of its first meeting after the completion of the review, whether to continue, modify or terminate such dispute settlement rules and procedure'. ${ }^{10}$

In spite of the very broad and unhindered mandate and lack of sensitive issues in the negotiations between 1995 and 1999, members were unable to meet either the January 1999 or the extended July 1999 deadline to complete preliminary negotiations on amendment of the DSU. While remedies, remand, amicus briefs and precedent had already started emerging as issues of potential concern in the WTO dispute settlement system, the issue of sequencing ${ }^{11}$ with regard to Articles 2.15 (compliance panel) and 22.6 (arbitration procedures) of the DSU almost provoked a major crisis in the system ${ }^{12}$ because of the peculiarity of the ongoing cases at the time. ${ }^{13}$ The sequencing issue was further considered by a group of countries spearheaded by Japan, and was resubmitted to the members as the socalled Suzuki Text ${ }^{14}$ in November 1999, before the failed Seattle Ministerial Conference in December 1999, and thereafter to the General Council in

10 Third tier of the Decision on the Application and Review of the Understanding on Rules and Procedures Governing the Settlement of Disputes, The Legal Texts: The Results of the Uruguay Round of Multilateral Trade Negotiations (Cambridge University Press, 2002), p. 408.

11 As a result of the EC-Bananas saga, there were sharp differences between the two major users, the European Communities and the United States, on the question of whether the procedures under Article 21.5 of the DSU should be exhausted if there is disagreement as to the measures taken by the losing party to comply with the recommendations and rulings of the DSB before recourse may be made to Article 22 of the DSU.

12 Article 21.5 (compliance panel) was initiated for the first time in late 1998 in the Bananas case. The EC and the US were very much in disagreement in this case as to whether a request for authorisation to suspend concession should take priority over a request for the establishment of a compliance panel to assess whether the measures the EC had put in place sufficiently met the DSB's recommendations.

13 See for instance the comments of members in the minutes of the Meeting of Special Session of the DSB, 22 October 2004, TN/DS/M/20.

14 See WT/MIN(99)/8; 22 November 1999. 
September 2000 ${ }^{15}$ Throughout the negotiations, until 2001 (when the Doha Ministerial Conference was launched) and beyond, the question of remedies for continuous non-compliance with an adopted Dispute Settlement Body (DSB) report appeared to be one of the issues most likely to cause divisions among members. The reason for this may be linked to what some consider the 'revolutionary' aspects of the proposals, the changing fundamentals of the international financial system and lack of political will on the part of negotiators to 'rock the boat'. There have been disagreements among members as regards proposals such as early determination of injuries once nullification and impairment have been established, negotiable remedies, preventive measures, collective countermeasures, and so on.

Although there is broad consensus on the importance of the WTO dispute settlement system, and the mandate accorded by ministers to negotiators in November 2001 to continue the negotiations on the improvements and clarifications' of the DSU was relatively uncomplicated, constructive ambiguity continues to impede progress in the negotiations on amendment and clarifications of the DSU pursuant to paragraph 30 of the Doha Ministerial Declaration. ${ }^{16}$ Even though more than 13 years had elapsed since the launch of the Round, ministers meeting in Geneva in December 2011 during the eighth WTO Ministerial Conference barely discussed issues relating to WTO disputes settlement reforms at all. ${ }^{17}$ As mentioned above, even the work of the independent experts appointed to establish a proper framework on dealing with institutional challenges affecting the future of the WTO has been criticised for having not added very much, in the domain of remedies for non-compliance, to the existing work of international economic lawyers such as John Jackson who sat on the panel. ${ }^{18}$ Yet, with

15 Proposal to Amend Certain Provisions of the Understanding on Rules and Procedures Governing the Settlement of Disputes (DSU) Pursuant to Article X of the Marrakesh Agreement Establishing the World Trade Organization, WT/ GC/W/410, 29 September 2000 and Rev.1.

16 Paragraph 30 of the Doha Declaration states 'members agree to negotiations on improvements and clarifications of the Dispute Settlement Understanding'.

17 The WTO Eighth Ministerial Conference took place in Geneva from 15-17 December 2011. See www.wto.org/english/thewto_e/minist_e/min11_e/ min11_e.htm (last visited 30 December 2011). Most WTO members, especially the small, vulnerable economies, regretted the outcome of the conference. See, for instance, the interview with the representative of the Solomon Islands in one of their local newspapers (the Solomon Star) at www.solomonstarnews.com/news/ national/13273-we-are-all-losers-today-sisilo-tells-wto-ministerial-conference (last visited 30 December 2011).

18 See von Bogdandy and Markus Wagner, p. 442. But there are also some positive appraisals of the way in which the report dealt overall with the issues 
respect to dispute settlement, one must admit that the Sutherland Report to some extent provides useful comments on some relevant legal issues which have always been contested by academics. Such topics include questions relating to precedents, ${ }^{19}$ standard of review (that is, de novo review or total deference) and deference by panels and the $\mathrm{AB}$, amicus briefs ${ }^{20}$ and some of the conceptual comments on DSU reform proposals put forward by WTO members in the context of the Doha trade talks. ${ }^{21}$

However, the consultative board's report failed to sufficiently respond to some fundamental international economic law questions that have for a long time been the subject of vigorous debate within international legal scholarship. The report admits the already widely accepted view that other international law has relevance in the WTO jurisprudence. However, in doing so, it cautions against pushing such a view too far without actually delving further into the extent to which international law should be seen as part of the WTO system of law. Given that various remedies exist for breach of an international obligation under general international law, the issue of international law's place in the WTO acquis remains very relevant to the debate on compliance with WTO law. ${ }^{22}$ This is the more so because we have witnessed in recent years growing intercourse between WTO rules and other international law rules. In a number of cases the panels and the

entrusted to it. On this point, see Richard Blackhurst, 'The Future of the WTO: Some comments on the Sutherland Report', World Trade Review, Vol. 4, No. 3 (2005), pp.378-89; and Niall Meagher, 'So far, so good: but what next? The Sutherland Report and WTO dispute settlement', World Trade Review, Vol. 4, No. 3 (2005), pp. 409-17.

19 The report rightly pointed out that although the strictest type of precedent as utilised in many common law jurisdictions may not be applicable in international proceedings like the WTO dispute settlement system, 'it is quite clear that some degree of "precedent" concepts motivates the WTO dispute settlement processes'. See para. 231 of the Sutherland Report.

20 As the report pointed out, through jurisprudential progressivism, the panels and the AB have followed the procedure laid down in Article 13 of the DSU and also regulated the issue of amicus curiae briefs on a case-by-case basis. Nonetheless, it is important, as the Sutherland Report notes, for WTO members to 'develop a general criteria and procedures, at both levels to fairly and adequately handle amicus submissions' (para. 260 of the Report).

21 Sutherland Report, pp.51 and 56-9.

22 The link between the WTO and other rules of international law has traditionally been provided by Article 3.2 of the DSU on customary rules of interpretation. Articles 31 and 32, in particular Article 31.3(c), of the VCLT have always been viewed by the DSB as a codification of the customary rules of interpretation and are, as such, the centre of the universe as far as this debate is concerned. Obviously, specific WTO-covered agreements, such as TRIPS, TBT, SPS, etc., contain specific references to other international rules outside the WTO treaty provisions. 
Appellate Body $(\mathrm{AB})$ have referred to other international law practices unrelated to treaty interpretation. These include locus standi, ${ }^{23}$ the precautionary principle, ${ }^{24}$ jura novit curia ${ }^{25}$ no retroactive application of treaties ${ }^{26}$ and manifest error in the formation of a treaty, and so on. ${ }^{27}$ Moreover, both the WTO members ${ }^{28}$ and the AB have also referred to certain of the international law concepts ingrained in the law of state responsibility. ${ }^{29}$

Further, while recognising the development of a vast amount of jurisprudence in the WTO, the Report also elaborates on the nature of the WTO DSU remedies regime under Articles 21 and 22 of the DSU as a lex specialis or confined regime. In circumscribing the remedies regime as one different from conceptual international law remedies, the report fails to deal with the issue of restitutio in integrum, which has been vigorously debated over the past years. Although rationality would lead one to assume that the maxim ubi jus, ibi remedium ${ }^{30}$ applies, there seems to be a lack of realisation of the role third parties/participants and other non-

23 See European Communities - Regime for the Importation, Sale and Distribution of Bananas (EC - Bananas), WT/DS27/R, para. 133 (27 September 1997). It is also important to note in this context that the panel and the AB in the Bananas case went so far as to utilise the Lomé Convention, which is not part of general international law.

24 Appellate Body Report, EC-Hormones case, paras. 123-4.

25 Appellate Body Report, EC-Tariff Preferences, para. 105.

26 Appellate Body Report, Brazil - Desiccated Coconut, pp. 15 and 167 at paras. 179-80.

27 In dealing with the issue of error in treaty formation, under the concept of non-violation complaint, the panel in Korea - Measures Affecting Government Procurement, WT/DS163/R (May 2000) resorted to customary international law practice (from the Permanent Court of International Justice (PCIJ) and the International Court of Justice (ICJ)), as codified in Article 48 of the VCLT 48. See panel report, paras. 7.120-7.123.

28 See, for instance, more recently China's arguments in US-Antidumping and Countervailing Duties (China), Appellate Body Report, United States - Definitive Anti-Dumping and Countervailing Duties on Certain Products from China, WT/ DS379/AB/R (adopted 25 March 2011), paras. 22, 36-41 and 305.

29 See, for instance, para. 259 of the Appellate Body Report, US - Line Pipe on the principle of proportionality of countermeasures. Moreover, in para. 20 of US - Cotton Yarn (Appellate Body Report, United States - Transitional Safeguard Measure On Combed Cotton Yarn from Pakistan, WT/DS192/AB/R (adopted 5 November 2001)) the AB stated: 'Our view is supported further by the rules of general international law on state responsibility, which require that countermeasures in response to breaches by states of their international obligations be commensurate with the injury suffered.'

30 A Latin maxim, which means 'where there is law, there is remedy'. See The Code of Justinian, 'Corpus Juris Civilis', The Attorney's Pocket Dictionary (Oxford University Press, 2001), pp. 527-65. 
disputing parties may play in effecting compliance with WTO obligations. In view of the fact that the WTO may be seen as an organisation based on trade-related agreements, one would have expected an approach to handling some of the twenty-first-century challenges facing the world trading system to also look closely into situations where some remedies for breaches of these agreements are somewhat systemic in nature.

In view of some of the issues highlighted above, we hope in this volume to further explore issues of compliance with WTO law. The volume employs some key international relation theories to conceptualise the arguments on how and why states comply or fail to comply with WTO rules. While the first few chapters deal with the general evolution of WTO dispute settlement and perspectives on different theories of compliance with international law, the second part focuses more on China and the WTO. The lack of progress in the Doha trade negotiations provides a compelling rationale for such an exercise. Moreover, apart from offering insights into the remedies available for non-compliance with legal obligations in WTO law, the book provides a systematic account of how the issue of rule of law and compliance with international trade rules have interacted with Chinese Confucian theory.

In view of the foregoing, as a multilateral institution which, as of May 2015, has 161 members, the WTO is something of a focal point for the major legal systems around the world. In addition to its developed members, emerging economies such as Brazil, China, India and Mexico have increasingly participated in the organisation's activities, especially in respect of its dispute settlement mechanism. For instance, since joining the WTO in 2001, China has been party either as complainant or respondent to more than 58 disputes. ${ }^{31}$ This therefore begs some interesting questions on the approach taken by each member to compliance and dispute resolution in the world trading system. Confucian values, identified as the foundation of China's great cultural tradition, have controlled the social order and regulated people in all activities of Chinese daily lives including the people's legal consciousness, expectations of justice and trust in law. This legal tradition is distinct from the common and civil law of Western society. This book accordingly examines the conflicting and conciliating processes between the Chinese approach to litigation and the Western, legally oriented, approach in the field of the WTO dispute settlement mechanism. In so doing, the evolution of the WTO dispute settlement system is traced.

\footnotetext{
$31 \quad$ As of May 2015.
} 